\title{
Variations in the Sensitivity of Phytophthora infestans Isolates from Different Genetic Backgrounds to Dimethomorph
}

\author{
J. M. Stein, Texas Agriculture Experiment Station, Bushland 79012; and W. W. Kirk, Department of Plant Pathol- \\ ogy, Michigan State University, East Lansing 48824
}

\begin{abstract}
Stein, J. M., and Kirk, W. W. 2003. Variations in the sensitivity of Phytophthora infestans isolates from different genetic backgrounds to dimethomorph. Plant Dis. 87:1283-1289.

The sensitivities of 11 isolates of Phytophthora infestans to dimethomorph were examined at all stages of the asexual life cycle and when inoculated onto potato leaf discs. In vitro zoospore encystment and cyst germination were highly sensitive to dimethomorph with $50 \%$ reduction of mycelial growth and cyst germination $\left(\mathrm{EC}_{50}\right.$ ) values for most isolates $<0.20 \mu \mathrm{g} / \mathrm{ml}$, whereas direct sporangia germination and in vitro hyphal growth and sporulation were less sensitive (means of 0.45 and $0.22 \mu \mathrm{g} / \mathrm{ml}$, respectively). Zoosporogenesis was not significantly inhibited at the maximum dimethomorph concentration examined, $10 \mu \mathrm{g} / \mathrm{ml}$. Significant differences (Fisher's least significant difference, $P=0.05$ ) in the $\mathrm{EC}_{50}$ values were present between isolates for all stages of the asexual life cycle, except direct sporangia germination and zoosporogenesis. Sensitivity ratios between the least- and most-sensitive isolates were 6.11, 12.14, 12.36, and 10.56 for hyphal growth, in vitro sporulation, zoospore encystment, and cyst germination, respectively. Application of dimethomorph at $1,000 \mu \mathrm{g} / \mathrm{ml}$ to potato leaf discs at 24 or 48 $\mathrm{h}$ before inoculation completely inhibited symptom incidence for most isolates, whereas application after inoculation generally was not significantly different from the untreated control, regardless of concentration. Sporulation from leaf discs treated with dimethomorph at 24 or 48 $\mathrm{h}$ after inoculation was completely inhibited for all isolates with dimethomorph at $1,000 \mu \mathrm{g} / \mathrm{ml}$, even when symptom incidence was not significantly reduced.
\end{abstract}

Additional keywords: antisporulation, fungicide, Oomycete, Solanum tuberosum

Dimethomorph, a cinnamic acid derivative, was one of the fungicides released for use in the United States following the migration (14) or spontaneous development (27) of phenylamide-resistant strains of Phytophthora infestans. Initial studies with dimethomorph demonstrated specific activity toward the genus Phytophthora and certain members of the family Peronosporaceae (1). Dimethomorph has a moderate amount of translaminar and acropetal systemicity $(1,9)$ and is most effective when used as a protectant fungicide; however, it has some degree of post-infection activity. One of the most interesting aspects of dimethomorph activity is its "antisporulation" activity; dimethomorph inhibits $P$. infestans sporangia formation (sporulation) when applied to inoculated potato (Solanum tuberosum) plants (9) or

Corresponding author: W. W. Kirk

E-mail: kirkw@msu.edu

This research was funded in part by BASF Corporation.

Accepted for publication 28 May 2003.

Publication no. D-2003-0818-02R

(c) 2003 The American Phytopathological Society leaf discs $(2,9)$ prior to symptom development.

The biochemical mode of action of dimethomorph has not been elucidated but a disruption of cell wall formation, specifically the organization and not the synthesis of wall components, has been described $(1,17)$. Dimethomorph disrupts all stages of the asexual life cycle of $P$. infestans except zoosporogenesis, zoospore release, and zoospore motility $(2,9,17)$, because these stages do not involve cell wall formation. The activity of dimethomorph on other Phytophthora spp. has been examined and found to be similar to that in $P$. infestans (19). However, differences in the effective concentration for a $50 \%$ reduction of mycelial growth and cyst germination relative to the untreated control $\left(\mathrm{EC}_{50}\right)$, were apparent among species.

The majority of studies examining dimethomorph activity against Phytophthora spp. typically consisted of only one isolate per species $(2,4,17,18)$. The single study that compared the sensitivity of eight isolates of $P$. infestans to dimethomorph examined only the in vivo sensitivity range and not differences in sensitivities at various stages of the asexual life cycle or antisporulation activity (9). Variations in the sensitivity of $P$. infestans to dimethomorph under field conditions has been noted (10); however, comparisons of the sensitivity of isolates from different genetic backgrounds is lacking.

The objectives of this study were to determine (i) the in vitro variation in dimethomorph sensitivity of 11 isolates of $P$. infestans from different genetic backgrounds at multiple stages in the asexual life cycle of $P$. infestans and (ii) the protectant, post-infection, and antisporulant activity of dimethomorph on these isolates when inoculated onto potato leaves.

\section{MATERIALS AND METHODS}

Preparation of amended media and fungicide stock solutions. Assessment of the inhibition of in vitro hyphal growth rate and sporulation was performed on modified rye B agar $(2,6)$ consisting of the filtrate of prerinsed rye (Secale cereale) seed (100 g/liter) boiled for $1 \mathrm{~h}$, deionized (d) $\mathrm{H}_{2} \mathrm{O}$ added to a final volume of 1.0 liter, glucose (8.0 g/liter), $\beta$-sitosterol (0.05 $\mathrm{g} /$ liter), and agar (15.0 g/liter). All plates for each of the experiments were prepared from the same batch of media in order to reduce variability.

Dimethomorph (BASF Corp, Research Triangle Park, NC) $100 \times$ stock solutions were prepared by dissolving technical grade (95\% active) dimethomorph into 95\% ethanol and performing serial dilutions as required in $95 \%$ ethanol. The stock solutions were added to molten media at 10 $\mathrm{ml} /$ liter when the temperature was cooled to approximately $55^{\circ} \mathrm{C}$ in a water bath. Fungicide solutions were passed through a $0.22-\mu \mathrm{m}$ syringe-driven filter (Millipore Corp., Bedford, MA) to sterilize. Control plates received filter-sterilized ethanol at $10 \mathrm{ml} /$ liter.

Calculation of $\mathrm{EC}_{50}$ values and statistical analysis. Each dimethomorph concentration (treatment) was replicated three times and each experiment was repeated three times for each variable examined. The percent inhibition relative to the control for an isolate was calculated for each replicate of a dimethomorph concentration with respect to the mean of the $0 \mu \mathrm{g} / \mathrm{ml}$ control replicates, within that experimental repeat. Percent inhibition values then were transformed using probits $(12,22)$ (i.e., the inverse of the standard normal distribution; 16), and expressed as a function of the 
$\log _{10}$ of concentration. Plot equation parameters were determined using linear regression (SigmaPlot; SPSS Inc., Chicago) and the $\mathrm{EC}_{50}$ for the inhibition of each variable (e.g., in vitro hyphal growth, zoospore encystment, and so on) was calculated and reverse transformed for every isolate examined. All measurements, calculations, transformations, and regressions were performed independently within each repeat of the experiment, and the $\mathrm{EC}_{50}$ values generated for each isolate from each repeat of an experiment were used as replicates for an analysis of variance (ANOVA) calculated as a randomized complete block design (Proc GLM, SAS/Stat; SAS Institute, Cary, NC). Means were separated by Fisher's least significant difference (LSD) at $P=0.05$.

Inhibition of hyphal growth and sporulation in vitro. Previously characterized isolates (Table 1) of $P$. infestans were subcultured once on modified rye $\mathrm{B}$ agar for 21 days at $18^{\circ} \mathrm{C}$ in the dark, following a single zoospore reisolation from infected potato leaves. Isolates obtained prior to 1997 probably had not been exposed to dimethomorph because the fungicide was on limited emergency registration in much of the United States from 1995 to 1997. Those isolates obtained in 1997 and 1998 may have been exposed to dimethomorph, although the likelihood is small because adoption by growers was minimal until 1999. Colonized 4-mm-diameter agar plugs were transferred from the margin of the colony onto dimethomorph-amended modified rye $\mathrm{B}$ media in 60 -mm-diameter plastic petri dishes and incubated at $21^{\circ} \mathrm{C}$. The dimethomorph concentrations used were $0,0.01,0.1,1$, and $10 \mu \mathrm{g} / \mathrm{ml}$. Colony diameter was measured 11 days after transferring to media. The percent inhibition relative to the $0 \mu \mathrm{g} / \mathrm{ml}$ control and $\mathrm{EC}_{50}$ values were calculated, and an ANOVA was performed as described above.

The effect of dimethomorph on in vitro sporulation was examined using a modification of a previously described method of sporangia quantification (6). Ten colonized agar plugs, $1 \mathrm{~mm}$ in diameter, were excised from each replicate plate of every dimethomorph concentration from the in vitro hyphal growth sensitivity assay. Five of the plugs were harvested at approximately $2 \mathrm{~mm}$ in from the colony margin and five approximately $2 \mathrm{~mm}$ out from the edge of the initial inoculum plug. All 10 plugs then were placed into a single $1.5-\mathrm{ml}$ microcentrifuge tube with $1.0 \mathrm{ml}$ of sterile (s) $\mathrm{dH}_{2} \mathrm{O}$ and agitated for $15 \mathrm{~s}$ using a laboratory vortex to dislodge the sporangia. Sporangia were quantified with a hemacytometer (average of four fields) and the number per square centimeter of colony area was calculated. The percent inhibition relative to the $0 \mu \mathrm{g} / \mathrm{ml}$ control and $\mathrm{EC}_{50}$ values were calculated, and an ANOVA was performed as described above.

Production of viable sporangia for germination studies and inoculations. To produce viable sporangia of similar age (11), potato tubers (cv. Russet Burbank) were surface disinfested with $0.5 \%$ sodium hypochlorite in $\mathrm{dH}_{2} \mathrm{O}(10 \%$ commercial bleach solution) for $30 \mathrm{~min}$, rinsed three times in $\mathrm{sdH}_{2} \mathrm{O}$, and allowed to dry. Tubers were sliced into 7-mm sections and placed into sterile $150-\mathrm{mm}$ (diameter) plastic petri dishes on top of $1 \mathrm{~cm}^{2}$ of modified rye $B$ agar sections previously colonized by individual isolates of $P$. infestans. Plates were sealed with Parafilm and incubated under fluorescent lighting with 12-h alternating cycles at $18^{\circ} \mathrm{C}$ (light) and $15^{\circ} \mathrm{C}$ (dark) until at least $50 \%$ of the tuber slice surface was covered by the mycelium (typically 5 days). Sporangia were harvested by gently removing the mycelium with a plastic culture spreader, transferred into sterile microcentrifuge tubes, and $1.0 \mathrm{ml}$ of $\mathrm{sdH}_{2} \mathrm{O}$ was added. Tubes were agitated using a laboratory vortex to dislodge sporangia and filtered through four layers of sterile cheesecloth to remove most of the mycelial fragments. Sporangia were quantified with a hemacytometer as described above and the concentration was adjusted to $1.0 \times 10^{4}$ sporangia/ml

Inhibition of direct sporangia germination, zoosporogenesis, zoospore encystment, and cyst germination in vitro.
To assess the effects of dimethomorph on direct sporangia germination, aliquots from the previously prepared suspension that contained approximately 100 sporangia (10 $\mu \mathrm{l})$ were added to $90 \mu \mathrm{l}$ of $\mathrm{sdH}_{2} \mathrm{O}$ in 96well Costar culture plates (Corning Inc., Acton, MA). Dimethomorph stock solutions were added for a final concentration of dimethomorph at $0,0.01,0.1,1$, or 10 $\mu \mathrm{g} / \mathrm{ml}$, in each of three replicate wells per concentration, per $P$. infestans isolate. Sporangia-fungicide suspensions were incubated for $72 \mathrm{~h}$ in the dark at $21^{\circ} \mathrm{C}$ and the numbers of total and germinated sporangia per well were quantified with a microscope. To examine zoosporogenesis and zoospore encystment, sporangia-fungicide suspensions were incubated in the dark at $8^{\circ} \mathrm{C}$ for $5 \mathrm{~h}$ to induce zoosporogenesis and the number of motile zoospores was quantified with a hemacytometer as described above. The zoospore suspensions then were incubated in the dark at $21^{\circ} \mathrm{C}$ and the number of total cysts per well was quantified microscopically after $24 \mathrm{~h}$. The number of cysts per well was adjusted based upon the number of zoospores removed during quantification. To examine cyst germination, zoospore suspensions were prepared as described above and incubated in the dark at $21^{\circ} \mathrm{C}$ for $24 \mathrm{~h}$ to allow for zoospore encystment. Fungicide solutions were added, the solutions were incubated in the dark at $21^{\circ} \mathrm{C}$ for $48 \mathrm{~h}$, and the number of total and germinated cysts was quantified with a hemacytometer. The percent inhibition relative to the $0 \mu \mathrm{g} / \mathrm{ml}$ control and $\mathrm{EC}_{50}$ values were calculated, and an ANOVA was performed as described above.

Protectant, post-infection, and antisporulant activity of dimethomorph in vivo. The in vivo activity of dimethomorph on the $P$. infestans isolates examined in the previous studies was measured with respect to the inoculation event. Fully expanded leaflets of similar age and from leaf positions 10 to 12 (mainstem, above the soil line) were excised from greenhousegrown potato plants (cv. Snowden) and surface disinfested in $0.5 \%$ sodium hypo-

Table 1. Phytophthora infestans isolate identification, year isolated, mating type, genotype, physiological race, state in which isolated (United States), and metalaxyl (phenylamide) sensitivity

\begin{tabular}{|c|c|c|c|c|c|c|}
\hline Isolate & Year isolated & Mating type & Genotypew $^{w}$ & Physiological race & Origin $y$ & Metalaxyl sensitivity \\
\hline Pi88 & 1995 & A1 & US1 & $3.6 .7 \cdot 10.11$ & North Dakota & nd \\
\hline Pi95-5 & 1995 & A1 & US1 & 1.2.3.7.9 & Michigan & $\mathrm{S}$ \\
\hline Pi671 & 1997 & A2 & US14 & 1.10 & Washington & nd \\
\hline Pi458 & 1998 & A1 & US17 & 1.2.3.4.5.6.7.9.11 & Idaho & nd \\
\hline Pi670 & 1997 & A2 & US7 & 1.2.3.4.5.6.10.11 & Oregon & nd \\
\hline Pi213 & 1997 & A2 & US8 & 1.2.3.4.5.6.7.10.11 & Colorado & $\mathrm{R}$ \\
\hline Pi94-4 & 1994 & $\mathrm{~A} 2$ & US8 & 1.3 .5 & Michigan & $\mathrm{R}$ \\
\hline Pi95-7 & 1995 & A2 & US8 & $1.2 .3 \cdot 4 \cdot 5 \cdot 6.7 \cdot 10.11$ & Michigan & $\mathrm{R}$ \\
\hline Pi97-2 & 1997 & $\mathrm{~A} 2$ & US8 & 1.3 .4 .5 .8 .11 & Michigan & $\mathrm{R}$ \\
\hline Pi98-1 & 1998 & A2 & US8 & $2 \cdot 5 \cdot 6 \cdot 7 \cdot 8 \cdot 9 \cdot 10.11$ & Michigan & $\mathrm{S}$ \\
\hline Pi98-2 & 1998 & A2 & US8 & $1 \cdot 2 \cdot 3 \cdot 4 \cdot 5 \cdot 7 \cdot 10.11$ & Michigan & $\mathrm{R}$ \\
\hline
\end{tabular}

\footnotetext{
${ }^{\mathrm{w}}$ Allozyme-based genotype (13).

${ }^{x}$ Determined using inoculations onto potato lines with different $R$ genes as described (3).

${ }^{y}$ State of origin. All isolates were obtained from potato.

${ }^{\mathrm{z}}$ Sensitivity to the fungicide metalaxyl assayed via the inhibition of in vitro hyphal growth: $\mathrm{nd}=$ not determined, $\mathrm{S}=$ sensitive, $\mathrm{R}=$ resistant $(23)$.
} 
chlorite in $\mathrm{dH}_{2} \mathrm{O}$ (10\% commercial bleach solution) for $1 \mathrm{~min}$. Leaflets were rinsed three times in $\mathrm{sdH}_{2} \mathrm{O}$, allowed to dry, and cut into 20-mm-diameter leaf discs with a sterilized cork borer. Leaf discs were pooled prior to being randomly assigned to treatments and placed onto water agar (15.0 g/liter) amended with rifamycin (37.5 $\mathrm{mg} / \mathrm{liter}$ ), ampicillin (10 mg/liter), and nystatin $(37.5 \mathrm{mg} / \mathrm{liter})$ which were previously dissolved in $1.0 \mathrm{ml}$ of dimethylsulfoxide, stored frozen $\left(-20^{\circ} \mathrm{C}\right)$ in the dark, and added to the molten media immediately prior to pouring. At $48 \mathrm{~h}$ after being placed onto agar, all leaf discs were inoculated with $50 \mu$ l (approximately 500 sporangia) of a single-isolate $P$. infestans sporangia suspension that had been incubated in the dark at $8^{\circ} \mathrm{C}$ for $5 \mathrm{~h}$ to induce zoosporogenesis. The zoospore number was not quantified, but the presence of active zoospores was confirmed microscopically. Four leaf discs were inoculated per treatment replicate, with three replicates of each dimethomorph concentration, and the experiment was repeated three times. Following inoculation, leaf discs were incubated at 21 and $18^{\circ} \mathrm{C}$ (light and dark, respectively in 12-h alternating cycles) and were removed temporarily from the agar at $48 \mathrm{~h}$ before inoculation (HBI), $24 \mathrm{HBI}, 24 \mathrm{~h}$ after inoculation (HAI), or 48 HAI for treatment. Dimethomorph was applied until run-off at $0,1,10,100$, or $1,000 \mu \mathrm{g} / \mathrm{ml}$ as the formulated commercial product, Acrobat 50WP (BASF Corp.) using a $\mathrm{CO}_{2}$-powered hand sprayer (344 $\mathrm{kPa}$ pressure) with a single XR11003VS spray nozzle (Spray Systems, Pomona, CA).

Leaf discs were assessed at $96 \mathrm{~h}$ after inoculation for symptoms and signs of infection by $P$. infestans, such as necrosis and sporulation. The mean incidence of infection of the four leaf discs (percentage that were symptomatic) was determined for each treatment replicate. The four leaf discs then were placed in a $15-\mathrm{ml}$ centrifuge tube containing $4.0 \mathrm{ml}$ of $\mathrm{dH}_{2} \mathrm{O}$ and agitated for $15 \mathrm{~s}$ using a laboratory vortex, after which sporangia were quantified with a hemacytometer. The number of sporangia per square centimeter of leaf disc area then was calculated for each treatment replicate. The percent inhibition relative to the 0 $\mu \mathrm{g} / \mathrm{ml}$ control and $\mathrm{EC}_{50}$ values were calculated, and an ANOVA was performed as described above. The contrast function in SAS/Stat was used to compare application timings before inoculation with those after inoculation for the inhibition of in vivo symptom incidence and sporulation.

\section{RESULTS}

Inhibition of hyphal growth and sporulation in vitro. For all isolates, no significant inhibition of hyphal growth (Fisher's LSD, $P=0.05$ ) was observed on media amended with dimethomorph at 0.01 $\mu \mathrm{g} / \mathrm{ml}$ (Fig. 1A). At a dimethomorph con- centration of $1 \mu \mathrm{g} / \mathrm{ml}$, more than $50 \%$ inhibition of hyphal growth occurred in all isolates, with $\mathrm{Pi} 95-5$ being completely inhibited. At a concentration of $10 \mu \mathrm{g} / \mathrm{ml}$, dimethomorph completely inhibited hyphal growth of all isolates. The calculated $\mathrm{EC}_{50}$ values for inhibition of hyphal growth by dimethomorph ranged from 0.13 to 0.80 $\mu \mathrm{g} / \mathrm{ml}$ (Table 2). Five nonoverlapping significance categories were detected, with the isolate $\mathrm{Pi} 213$ having a significantly higher $\mathrm{EC}_{50}$ value than all others for in vitro hyphal growth.

In contrast to in vitro hyphal growth, dimethomorph at $0.01 \mu \mathrm{g} / \mathrm{ml}$ had a pronounced effect on in vitro sporulation because isolate $\mathrm{Pi} 95-5$ was inhibited approximately $35 \%$ (Fig. 1B). Sensitivity of in vitro sporulation was more variable among isolates with dimethomorph at 0.01 and $0.1 \mu \mathrm{g} / \mathrm{ml}$ than at $1 \mu \mathrm{g} / \mathrm{ml}$, and complete inhibition occurred at $10 \mu \mathrm{g} / \mathrm{ml}$ for all isolates. The calculated $\mathrm{EC}_{50}$ values ranged from 0.04 to $0.44 \mu \mathrm{g} / \mathrm{ml}$ (Table 2) and the isolate Pi213 had a significantly higher $\mathrm{EC}_{50}$ value than isolates Pi95-5, Pi97-2, and Pi98-2.

Inhibition of direct sporangia germination, zoosporogenesis, zoospore encystment, and cyst germination in vitro. Direct sporangia germination was not inhibited in isolate Pi213 with dimethomorph at $0.01 \mu \mathrm{g} / \mathrm{ml}$, whereas the other 10 isolates were inhibited from 16 to $29 \%$ at this concentration (Fig. 1C). For most isolates, direct germination inhibition trends were similar to those of in vitro sporulation, except that dimethomorph at $10 \mu \mathrm{g} / \mathrm{ml}$ was not always completely inhibitory. No significant differences were calculated between isolates for the $\mathrm{EC}_{50}$ of inhibition of direct sporangia germination and $\mathrm{EC}_{50}$ values ranged from 0.096 to 0.231 , with a mean of $0.163 \mu \mathrm{g} / \mathrm{ml}$ (data not shown).

Zoosporogenesis was not significantly inhibited at any of the dimethomorph concentrations examined, up to $10 \mu \mathrm{g} / \mathrm{ml}$ (Fig. 1D). No significant differences in $\mathrm{EC}_{50}$ values were detected between isolates, and all exceeded $10 \mu \mathrm{g} / \mathrm{ml}$ (data not shown). Most isolates exhibited significant inhibition of zoospore encystment (Fig. 1E) and cyst germination (Fig. 1F) at $0.01 \mu \mathrm{g} / \mathrm{ml}$. Isolate Pi213 had a significantly higher $\mathrm{EC}_{50}$ value for zoospore encystment than did Pi88, Pi95-5, Pi94-4, and Pi97-2 (Table 2). For cyst germination, the $\mathrm{EC}_{50}$ values for Pi670 and Pi88 were significantly higher than 5 of the 11 isolates, and not significantly different from the remaining isolates.

Protectant, post-infection, and antisporulation activity of dimethomorph in vivo. Significant main effects of application timings, dimethomorph concentrations, and a significant timing $\times$ concentration interaction were detected for the inhibition of symptom incidence and sporulation following inoculation with $P$. infestans, whereas other factors and inter- actions were not significant (Table 3 ). The percent inhibition of symptom incidence values at each dimethomorph concentration was not significantly different between application timings on either side of the inoculation event (i.e., the 48- and 24-HBI application timings were not significantly different but were significantly different from the 24- and 48-HAI timings, and visa versa) (Fig. 2A). For application timings before inoculation, increasing the dimethomorph concentration resulted in significantly greater inhibition of symptom incidence. Application of dimethomorph after inoculation with $P$. infestans resulted in significantly lower values for the inhibition of symptom incidence at each concentration than the corresponding HBI timings, except for dimethomorph at $1 \mu \mathrm{g} / \mathrm{ml}$. Complete inhibition of symptom incidence occurred at $1,000 \mu \mathrm{g} / \mathrm{ml}$ for both HBI application timings, but was only inhibited to approximately $20 \%$ for both HAI timings.

The 24-HBI application timing had a significantly greater percent inhibition of sporulation than the 24-HAI timing for dimethomorph at $10 \mu \mathrm{g} / \mathrm{ml}$ and all other application timings at $100 \mu \mathrm{g} / \mathrm{ml}$ (Fig. 2B). Because symptoms did not develop on leaf discs treated before inoculation with dimethomorph at $1,000 \mu \mathrm{g} / \mathrm{ml}$, antisporulation could not be assessed at this concentration and application timing.

Significant main effects were detected with respect to the $\mathrm{EC}_{50}$ values for the application timing factor of the incidence of symptom development and sporulation in vivo, but not the isolate factor (Table 4). No isolate $\times$ timing interaction was detected. For the inhibition of symptom incidence, $\mathrm{EC}_{50}$ values for both application timings before inoculation were not significantly different, but were significantly different from both timings after inoculation (Table 5). Mean $\mathrm{EC}_{50}$ values for the inhibition of symptom incidence were 36.18 and $62.45 \times 10^{4} \mu \mathrm{g} / \mathrm{ml}$ for the before and after inoculation timings, respectively. For the inhibition of $P$. infestans sporulation by dimethomorph, the 24-HBI application timing had a significantly lower $\mathrm{EC}_{50}$ value than both HAI timings, while the 48-HBI timing was not significantly different from any other timing (Table 5). The $\mathrm{EC}_{50}$ values for the inhibition of sporulation ranged from 39.37 to 59.05 $\mu \mathrm{g} / \mathrm{ml}$. For both symptom incidence and sporulation the, contrast function comparing dimethomorph application before versus after inoculation was significant (Table 4).

\section{DISCUSSION}

The mean concentrations required for the inhibition of $P$. infestans in vitro hyphal growth, direct sporangia germination, zoospore encystment, cyst germination, and in vivo inhibition of symptom incidence and sporulation were similar to those previously reported for single isolates of $P$. in- 
festans $(1,2,9,17,19)$. The different stages of the $P$. infestans asexual life cycle showed a range of sensitivities to dimethomorph in vitro. Zoospore encystment and cyst germination appeared to be most sensitive to dimethomorph with mean $\mathrm{EC}_{50}$ values $<0.10 \mu \mathrm{g} / \mathrm{ml}$, whereas hyphal growth, sporulation, and direct sporangia germination were less sensitive with mean
$\mathrm{EC}_{50}$ values of $0.45,0.22$, and $0.19 \mu \mathrm{g} / \mathrm{ml}$, respectively.

Direct sporangia germination and in vitro hyphal growth had the smallest ranges in sensitivity between isolates, with fourand sixfold differences in $\mathrm{EC}_{50}$ values between the most- and least-sensitive isolates, respectively. The range of dimethomorph sensitivity for in vitro hyphal growth reported here is much smaller than those reported for phenylamide sensitivity in P. infestans (26) and other Phytophthora spp. $(12,21)$. However, the cited studies included isolates with field resistance to the phenylamides. Recalculating the sensitivity range using only the phenylamidesensitive isolates from these studies results in a sensitivity distribution for phenyla-
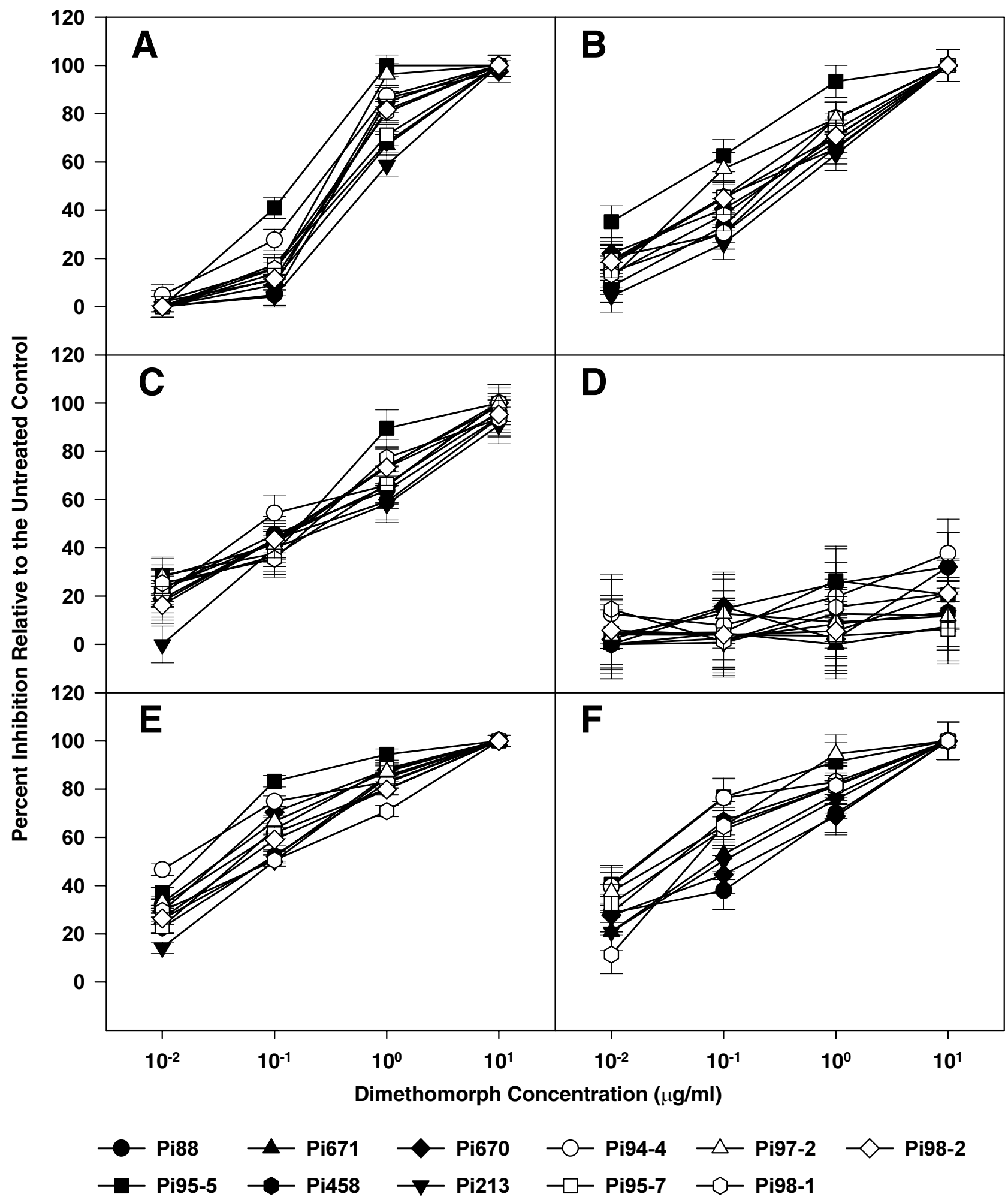

Fig. 1. Influence of dimethomorph concentration on in vitro A, hyphal growth and B, sporulation; C, direct sporangia germination; D, zoosporogenesis; E, zoospore encystment; and $\mathbf{F}$, cyst germination for 11 isolates of Phytophthora infestans. Error bars represent Fisher's least significant difference $(P=0.05)$. 
mides similar to the one reported here for $P$. infestans to dimethomorph. In vitro sporulation, zoospore encystment, and cyst germination all had larger ranges in sensi- tivity, with $>10$-fold differences. The ranges in sensitivity measured in this study probably are indicative of natural variations in the sensitivity of fungal and Oo-

Table 2. Effective concentration of dimethomorph required for a $50 \%$ reduction of in vitro hyphal growth (colony diameter), sporulation, zoospore encystment, and cyst germination for Phytophthora infestans isolates

\begin{tabular}{lcccc}
\hline & \multicolumn{4}{c}{ EC $_{\mathbf{5 0}}{\text { dimethomorph }(\boldsymbol{\mu g} / \mathbf{m l})^{\mathbf{v}}}$} \\
\cline { 2 - 5 } Isolate ID & Hyphal growth $^{\mathbf{w}}$ & Sporulation $^{\mathbf{x}}$ & Zoospore encystment $^{\mathbf{y}}$ & Cyst germination $^{\mathbf{z}}$ \\
\hline Pi88 & $0.43 \mathrm{c}$ & $0.20 \mathrm{abc}$ & $0.05 \mathrm{bc}$ & $0.17 \mathrm{a}$ \\
Pi95-5 & $0.13 \mathrm{e}$ & $0.04 \mathrm{c}$ & $0.02 \mathrm{bc}$ & $0.02 \mathrm{~d}$ \\
Pi671 & $0.63 \mathrm{~b}$ & $0.32 \mathrm{ab}$ & $0.07 \mathrm{abc}$ & $0.12 \mathrm{ab}$ \\
Pi458 & $0.59 \mathrm{~b}$ & $0.20 \mathrm{abc}$ & $0.08 \mathrm{abc}$ & $0.05 \mathrm{bcd}$ \\
Pi670 & $0.39 \mathrm{c}$ & $0.24 \mathrm{abc}$ & $0.04 \mathrm{bc}$ & $0.15 \mathrm{a}$ \\
Pi213 & $0.80 \mathrm{a}$ & $0.44 \mathrm{a}$ & $0.14 \mathrm{a}$ & $0.11 \mathrm{abc}$ \\
Pi94-4 & $0.27 \mathrm{~d}$ & $0.25 \mathrm{abc}$ & $0.01 \mathrm{c}$ & $0.02 \mathrm{~d}$ \\
Pi95-7 & $0.53 \mathrm{~b}$ & $0.17 \mathrm{abc}$ & $0.05 \mathrm{abc}$ & $0.04 \mathrm{bcd}$ \\
Pi97-2 & $0.29 \mathrm{~d}$ & $0.12 \mathrm{bc}$ & $0.03 \mathrm{bc}$ & $0.03 \mathrm{~cd}$ \\
Pi98-1 & $0.42 \mathrm{c}$ & $0.25 \mathrm{abc}$ & $0.10 \mathrm{ab}$ & $0.07 \mathrm{abcd}$ \\
Pi98-2 & $0.43 \mathrm{c}$ & $0.16 \mathrm{bc}$ & $0.06 \mathrm{abc}$ & $0.05 \mathrm{bcd}$ \\
\hline
\end{tabular}

${ }^{\mathrm{v}}$ Effective concentration for a $50 \%$ reduction, calculated using probit transformation of the percent inhibition relative to the untreated control. Means followed by the same letter are not significantly different using Fisher's least significant difference $(P=0.05)$.

${ }^{\mathrm{w}}$ Calculated from colony diameter on modified rye B media amended with dimethomorph.

${ }^{x}$ Production of sporangia per square centimeter of colony area on modified rye B media amended with dimethomorph.

y Encystment of zoospores in $\mathrm{sdH}_{2} \mathrm{O}$-amended with dimethomorph.

${ }^{\mathrm{z}}$ Germination of previously encysted zoospores in $\mathrm{sdH}_{2} \mathrm{O}$-amended with dimethomorph.

mycete plant pathogens, as noted with other fungicides $(15,20,26)$.

The higher dimethomorph sensitivity of the zoospore encystment and cyst germination stages of the $P$. infestans asexual life cycle may be related to the physiology of those stages. Exposure to dimethomorph has been shown to cause aberrant cell wall formation and thickening, eventually resulting in burst hyphal tips (17). Disruption of the de novo construction of the cell wall by dimethomorph, as in zoospore encystment, could be lethal in a short time period because zoospores have comparatively limited carbohydrate reserves to actively offset osmotic pressure and for use in cell wall formation (5). As with zoospores, cysts have relatively limited reserves, saprophytic ability, and longevity (8) and the inhibition of germ tube formation for penetration into the host plant cell would be lethal. The sporangial and hyphal stages are less sensitive, possibly because of their larger carbohydrate reserves and ability to tolerate multiple attempts at hyphal tip formation. Alternatively, the cell walls of the different stages of Phytophthora spp. have been found to vary in chemical composition and thickness (5), and it is possi-

Table 3. Summary of the analysis of variance of the incidence of symptom development or sporulation following inoculation of potato leaf discs by Phytophthora infestans for all 11 isolates, five dimethomorph concentrations applied at one of four application timings, and with three experimental repeats

\begin{tabular}{|c|c|c|c|c|c|}
\hline Sourcew $^{w}$ & $d f^{x}$ & Sum of squares ${ }^{y}$ & Mean square & $F$ value & $P$ value $^{z}$ \\
\hline \multicolumn{6}{|l|}{ Incidence of symptom development } \\
\hline Isolate & 10 & 0.50 & 0.05 & 0.38 & 0.9540 \\
\hline Repeat & 2 & 0.46 & 0.23 & 1.77 & 0.1702 \\
\hline Timing & 3 & 50.52 & 16.84 & 128.53 & $<0.0001$ \\
\hline Isolate $\times$ timing & 30 & 0.92 & 0.03 & 0.23 & 0.9999 \\
\hline Concentration & 4 & 102.10 & 25.52 & 194.82 & $<0.0001$ \\
\hline Isolate $\times$ concentration & 40 & 1.11 & 0.03 & 0.21 & 0.9999 \\
\hline Timing $\times$ concentration & 12 & 40.49 & 3.37 & 25.75 & $<0.0001$ \\
\hline Isolate $\times$ timing $\times$ concentration & 120 & 3.35 & 0.03 & 0.21 & 0.9999 \\
\hline Repeat $\times$ isolate & 20 & 3.76 & 0.19 & 1.43 & 0.0901 \\
\hline Repeat $\times$ timing & 6 & 0.90 & 0.15 & 1.15 & 0.3322 \\
\hline Repeat $\times$ isolate $\times$ timing & 60 & 6.23 & 0.10 & 0.79 & 0.8735 \\
\hline Repeat $\times$ concentration & 8 & 0.63 & 0.08 & 0.60 & 0.7791 \\
\hline Repeat $\times$ isolate $\times$ concentration & 80 & 6.15 & 0.08 & 0.59 & 0.9985 \\
\hline Repeat $\times$ timing $\times$ concentration & 24 & 0.95 & 0.04 & 0.30 & 0.9996 \\
\hline Repeat $\times$ isolate $\times$ timing $\times$ concentration & 240 & 12.89 & 0.05 & 0.41 & 0.9999 \\
\hline Error & 1,320 & 173.94 & 0.13 & $\ldots$ & $\ldots$ \\
\hline Total & 1,979 & 404.91 & $\ldots$ & $\ldots$ & $\ldots$ \\
\hline \multicolumn{6}{|l|}{ Sporulation } \\
\hline Isolate & 10 & 0.90 & 0.09 & 1.54 & 0.1196 \\
\hline Repeat & 2 & 0.03 & 0.02 & 0.28 & 0.7544 \\
\hline Timing & 3 & 0.90 & 0.30 & 5.10 & 0.0016 \\
\hline Isolate $\times$ timing & 30 & 2.39 & 0.08 & 1.35 & 0.0964 \\
\hline Concentration & 4 & 331.39 & 82.85 & $1,408.62$ & $<0.0001$ \\
\hline Isolate $\times$ concentration & 40 & 2.57 & 0.06 & 1.09 & 0.323 \\
\hline Timing $\times$ concentration & 12 & 1.43 & 0.12 & 2.03 & 0.0188 \\
\hline Isolate $\times$ timing $\mathrm{x}$ concentration & 120 & 4.52 & 0.04 & 0.64 & 0.9989 \\
\hline Repeat $\times$ isolate & 20 & 1.38 & 0.07 & 1.18 & 0.2672 \\
\hline Repeat $\times$ timing & 6 & 0.49 & 0.08 & 1.38 & 0.2191 \\
\hline Repeat $\times$ isolate $\times$ timing & 60 & 4.48 & 0.07 & 1.27 & 0.0839 \\
\hline Repeat $\times$ concentration & 8 & 0.14 & 0.02 & 0.30 & 0.9662 \\
\hline Repeat $\times$ isolate $\times$ concentration & 80 & 3.55 & 0.04 & 0.76 & 0.9458 \\
\hline Repeat $\times$ timing $\times$ concentration & 24 & 0.60 & 0.03 & 0.43 & 0.9932 \\
\hline Repeat $\times$ isolate $\times$ Timing $\times$ concentration & 240 & 9.81 & 0.04 & 0.70 & 0.9998 \\
\hline Error & 1,320 & 77.64 & 0.06 & $\ldots$ & $\ldots$ \\
\hline Total & 1,979 & 442.24 & $\ldots$ & $\ldots$ & $\ldots$ \\
\hline
\end{tabular}

${ }^{\mathrm{w}}$ Timing = application timings $48 \mathrm{~h}$ before, $24 \mathrm{~h}$ before, $24 \mathrm{~h}$ after, or $48 \mathrm{~h}$ after inoculation with $P$. infestans. Concentration $=$ dimethomorph concentration.

${ }^{x}$ Degrees of freedom.

y Type III sum of squares.

z Significance indicated by $P \leq 0.05$. 


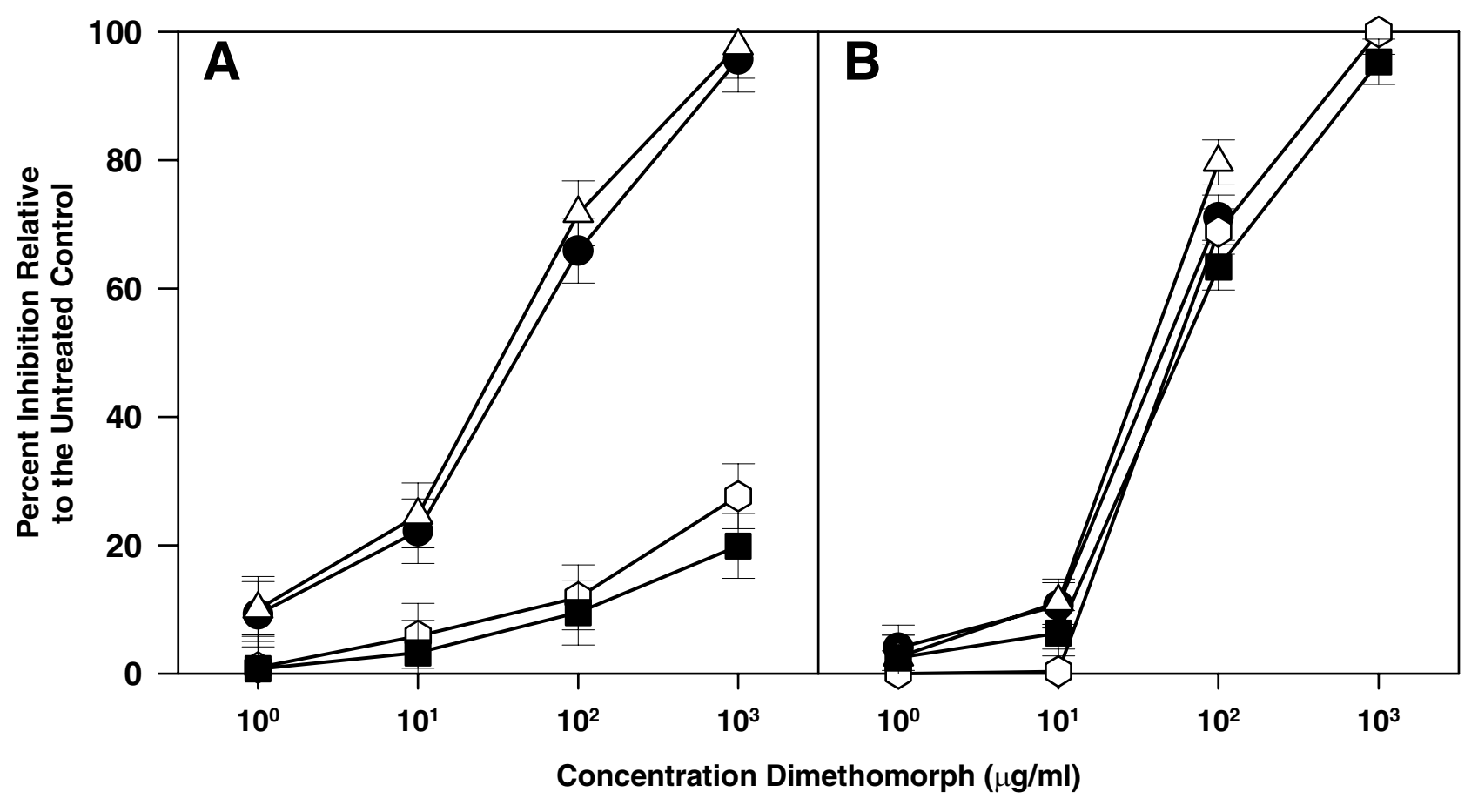

$-48 \mathrm{~h}$ Before $\triangle 24 \mathrm{~h}$ Before $-\mathrm{-}-24 \mathrm{~h}$ After $\rightarrow-48 \mathrm{~h}$ After

Fig. 2. Influence of dimethomorph concentration on A, symptom incidence and B, sporulation on potato leaf discs inoculated with Phytophthora infestans. Plots represent the mean of all 11 isolates when dimethomorph was applied at $48 \mathrm{~h}$ before, $24 \mathrm{~h}$ before, $24 \mathrm{~h}$ after, or $48 \mathrm{~h}$ after inoculation with $P$. infestans. Error bars represent Fisher's least significant difference $(P=0.05)$.

Table 4. Summary of the analysis of variance of the effective concentration of dimethomorph $(\mu \mathrm{g} / \mathrm{ml})$ required for a $50 \%$ reduction of in vivo symptom incidence and sporulation from potato leaf discs, when applied at $48 \mathrm{~h}$ before, $24 \mathrm{~h}$ before, $24 \mathrm{~h}$ after, or $48 \mathrm{~h}$ after inoculation with Phytophthora infestans

\begin{tabular}{|c|c|c|c|c|c|}
\hline Source ${ }^{w}$ & $\mathbf{d f}^{\mathrm{x}}$ & Sum of squares ${ }^{y}$ & Mean square & $F$ value & $P$ value $^{\mathrm{z}}$ \\
\hline \multicolumn{6}{|c|}{ Incidence of symptom development } \\
\hline Isolate & 10 & $9.58 \times 10^{11}$ & $9.58 \times 10^{11}$ & 0.66 & 0.7576 \\
\hline Repeat & 2 & $5.35 \times 10^{11}$ & $2.67 \times 10^{11}$ & 1.84 & 0.1647 \\
\hline Timing & 3 & $1.29 \times 10^{13}$ & $4.29 \times 10^{12}$ & 29.57 & $<0.0001$ \\
\hline Isolate $\times$ timing & 20 & $2.44 \times 10^{12}$ & $8.14 \times 10^{10}$ & 0.56 & 0.9622 \\
\hline Error & 86 & $1.25 \times 10^{13}$ & $1.45 \times 10^{11}$ & $\ldots$ & $\ldots$ \\
\hline Total & 131 & $2.93 \times 10^{13}$ & & $\ldots$ & $\ldots$ \\
\hline Contrast for timing & 1 & 1.29 & 1.29 & 88.69 & $<0.0001$ \\
\hline \multicolumn{6}{|l|}{ Sporulation } \\
\hline Isolate & 10 & $9,237.78$ & 923.78 & 1.91 & 0.0551 \\
\hline Repeat & 2 & 548.27 & 274.13 & 0.57 & 0.5702 \\
\hline Timing & 3 & 6481.21 & $2,160.40$ & 4.46 & 0.0059 \\
\hline Isolate $\times$ timing & 20 & $16,249.55$ & 541.65 & 1.125 & 0.3373 \\
\hline Error & 86 & $41,690.82$ & 484.78 & $\ldots$ & $\ldots$ \\
\hline Total & 131 & $74,207.63$ & & $\ldots$ & $\ldots$ \\
\hline Contrast for timing & 1 & $5,083.88$ & $5,083.88$ & 10.49 & 0.0017 \\
\hline
\end{tabular}

${ }^{\mathrm{w}}$ Timing = application timings $48 \mathrm{~h}$ before, $24 \mathrm{~h}$ before, $24 \mathrm{~h}$ after, or $48 \mathrm{~h}$ after inoculation with $P$. infestans.

${ }^{x}$ Degrees of freedom.

y Type III sum of squares.

${ }^{z}$ Significance indicated by $P \leq 0.05$.

ble that the biochemical basis of these variations may be associated with the different levels of sensitivity to dimethomorph. The true reason or reasons for the variations in sensitivity will not be understood until the biochemical mode of action of dimethomorph is known.

The full-label field rate (United States) of dimethomorph, assuming a carrier volume of 234 liter/ha, is approximately 1,000 $\mu \mathrm{g} / \mathrm{ml}$. Application of the full rate of dimethomorph at 24 or $48 \mathrm{~h}$ before inoculation almost completely inhibited symptom incidence in inoculated leaf discs, whereas application within $48 \mathrm{~h}$ after inoculation failed to offer significant inhibition. When used to control $P$. infestans in the field, dimethomorph should be applied in a protectant fashion, reinforcing previously reported results $(1,9,24)$. The $\mathrm{EC}_{50}$ values for the inhibition of in vivo symptom incidence were much larger than those at specific stages in the asexual life cycle of $P$. infestans in vitro, as has been noted previously with $P$. infestans (23), and is most likely attribut- able to the dilution or metabolism of dimethomorph in planta.

Inhibition of sporulation of $P$. infestans occurred when dimethomorph was applied between $48 \mathrm{~h}$ before and $48 \mathrm{~h}$ after inoculation at concentrations of $100 \mu \mathrm{g} / \mathrm{ml}$ or higher. These results are similar to those previously reported (9). Outside of the examined time frame and under field conditions, dimethomorph may not have the same level of antisporulant activity. A previous study conducted by the authors examined sporulation under field conditions 
Table 5. Effective concentration of dimethomorph required for a 50\% reduction of in vivo symptom incidence and sporulation from potato leaf discs, when applied at $48 \mathrm{~h}$ before, $24 \mathrm{~h}$ before, $24 \mathrm{~h}$ after, or $48 \mathrm{~h}$ after inoculation with Phytophthora infestans

\begin{tabular}{|c|c|c|}
\hline \multirow[b]{2}{*}{ Application timingy } & \multicolumn{2}{|c|}{$\mathrm{EC}_{50}$ dimethomorph $(\mu \mathrm{g} / \mathrm{ml})^{\mathrm{x}}$} \\
\hline & Symptom incidence & Sporulation $^{\mathrm{z}}$ \\
\hline $48 \mathrm{HBI}$ & $39.62 \mathrm{~b}$ & $47.37 \mathrm{ab}$ \\
\hline $24 \mathrm{HBI}$ & $32.73 \mathrm{~b}$ & $39.37 \mathrm{~b}$ \\
\hline $24 \mathrm{HAI}$ & $62.86 \times 10^{4} \mathrm{a}$ & $53.51 \mathrm{a}$ \\
\hline $48 \mathrm{HAI}$ & $62.03 \times 10^{4} \mathrm{a}$ & $59.05 \mathrm{a}$ \\
\hline
\end{tabular}

${ }^{\mathrm{x}}$ Effective concentration for a 50\% reduction, calculated using probit transformation of the percent inhibition relative to the untreated control. Means followed by the same letter are not significantly different using Fisher's least significant difference $(P=0.05)$.

${ }^{y}$ Mean values pooled across isolates. $\mathrm{HBI}=$ hours before inoculation and HAI $=$ hours after inoculation.

${ }^{\mathrm{z}}$ Production of sporangia per square centimeter of leaf disc.

and failed to detect any inhibition of sporulation following dimethomorph applications (25). Application of fungicides under field conditions is unlikely to confer the same homogeneity of leaf coverage as application under controlled conditions. Thus, the lack of antisporulation activity in field conditions when dimethomorph is applied within $48 \mathrm{~h}$ of the infection event is likely due to incomplete coverage, subefficacious concentrations through dilution or metabolism in planta, or a combination of these factors.

The results of the in vitro assays demonstrated that dimethomorph is most active against zoospore encystment and cyst germination in addition to having an effect on hyphal growth, sporangia formation, and germination. Frequent protectant applications of dimethomorph at concentrations of $1,000 \mu \mathrm{g} / \mathrm{ml}$ would likely inhibit infection by $P$. infestans in the field and possibly reduce sporulation from previously established infections, but not eliminate them. The inhibition of $P$. infestans zoospore encystment and cyst germination by dimethomorph, in combination with a reduction in sporulation from infected foliar tissue, will likely have a larger impact upon epidemic development than the inhibition of the infectious stages of the asexual lifecycle alone. The $P$. infestans isolates examined all had similar sensitivity to dimethomorph in the assays performed. Isolates exhibiting low levels of resistance to dimethomorph have been generated in vitro for P. infestans (27) and other Phytophthora spp. $(7,27)$; however there has been no conclusive evidence of the development of practical resistance to dimethomorph in $P$. infestans. Nevertheless, resistance monitoring and management are important for this fungicide, and resistance development should be examined further.

\section{ACKNOWLEDGMENTS}

We thank B. Dunlap for technical assistance.

\section{LITERATURE CITED}

1. Albert, G., Curtze, J., and Drandarevski, C. A. 1988. Dimethomorph (CME 151), a novel curative fungicide. Proc. Brighton Crop Prot. Conf. Pests Dis. 1:17-24.

2. Albert, G., Thomas, A., and Guhne, M. 1991. Fungicidal activity of dimethomorph on different stages in the life cycle of Phytophthora infestans and Plasmopara viticola. ANPPThird International Conference on Plant Diseases, Bordeaux, France.

3. Al-Kherb, S. M., Fininsa, C., Shattock, R. C., and Shaw, D. S. 1995. The inheritance of virulence of Phytophthora infestans to potato. Plant Pathol. 44:552-562.

4. Andrieu, N., Jaworska, G., Genet, J. L., and Bompeix, G. 2001. Biological mode of action of famoxadone on Plasmopara viticola and Phytophthora infestans. Crop Prot. 20:253260.

5. Bartnicki-Garcia, S., and Wang, M. C., 1983. Biochemical aspects of morphogenesis in Phytophthora. In: Phytophthora; Its Biology, Taxonomy, Ecology, and Pathology. D. C. Erwin, S. Bartnicki-Garcia, and P. H. Tsao, eds. American Phytopathological Society Press, St. Paul, MN.

6. Caten, C. E., and Jinks, J. L. 1968. Spontaneous variability of single isolates of Phytophthora infestans. I. Cultural variations. Can. J. Bot. 46:329-348.

7. Chabane, K., Leroux, P., and Bompeix, G. 1993. Selection and characterization of Phytophthora parasitica mutants with ultravioletinduced resistance to dimethomorph or metalaxyl. Pestic. Sci. 39:325-329.

8. Coffey, M. D., and Gees, R. 1991. The cytology of development. In: Advances in Plant Pathology. Phytophthora infestans, the Cause of Potato Late Blight. P. H. Williams, ed. Academic Press Limited, San Diego, CA.

9. Cohen, Y., Balder, A., and Cohen, B. H. 1995. Dimethomorph activity against Oomycete fungal plant pathogens. Phytopathology $85: 1500-1506$

10. Dereviagina, M. K., Elanskij, S. N., and Diakov, Y. T. 1999. Resistance of Phytophthora infestans to the dimethomorph fungicide. Mikologiya Fitopatol. 33:208-213.

11. Dorrance, A. E., and Inglis, D. A. 1998. Assessment of laboratory methods for evaluating potato tubers for resistance to late blight. Plant Dis. 82:442-446.

12. Ferrin, D. M., and Kabashima, J. N. 1991. In vitro insensitivity to metalaxyl of isolates of
Phytophthora citricola and $P$. parasitica from ornamental hosts in southern California. Plant Dis. 75:1041-1044.

13. Goodwin, S. B., Schneider, R. E., and Fry, W. E. 1995. Use of cellulose-acetate electrophoresis for rapid identification of allozyme genotypes of Phytophthora infestans. Plant Dis. 79:1181-1185.

14. Goodwin, S. B., Sujkowski, L. S., and Fry, W E. 1996. Widespread distribution and probable origin of resistance to metalaxyl in clonal genotypes of Phytophthora infestans in the United States and western Canada. Phytopathology 86:793-800.

15. Hamlen, R. A., and Power, R. J. 1998. Distribution of sensitivity responses to cymoxanil within global populations of Phytophthora infestans. Pestic. Sci. 53:101-103.

16. Kuehl, R. O. 1994. Statistical Principles of Research Design and Analysis. Duxbury Press, Belmont, CA.

17. Kuhn, P. J., Pitt, D., Lee, S. A., Wakley, G., and Sheppard, A. N. 1991. Effects of dimethomorph on the morphology and ultrastructure of Phytophthora. Mycol. Res. 95:333-340.

18. Matheron, M. E., and Porchas, H. 2000. Comparison of five fungicides on development of root, crown, and fruit rot of chili pepper and recovery of Phytophthora capsici from soil. Plant Dis. 84:1038-1043.

19. Matheron, M. E., and Porchas, M. 2000 Impact of azoxystrobin, dimethomorph, fluazinam, fosetyl-al, and metalaxyl on growth, sporulation, and zoospore cyst germination of three Phytophthora spp. Plant Dis. 84:454458.

20. Olaya, G., and Koller, W. 1999. Diversity of kresoxim-methyl sensitivities in baseline populations of Venturia inaequalis. Pestic. Sci. 55:1083-1088.

21. Parra, G., and Ristaino, J. B. 2001. Resistance to mefenoxam and metalaxyl among field isolates of Phytophthora capsici causing Phytophthora blight of bell pepper. Plant Dis. 85:1069-1075.

22. Smith, F. D., Phipps, P. M., and Stipes, R. J. 1991. Agar plate, soil plate, and field-evaluation of fluazinam and other fungicides for control of Sclerotinia minor on peanut. Plant Dis. 75:1138-1143.

23. Sozzi, D., and Staub, T. 1987. Accuracy of methods to monitor sensitivity of Phytophthora infestans to phenylamide fungicides. Plant Dis. 71:422-425.

24. Stein, J. M., and Kirk, W. W. 2002. Containment of existing potato late blight (Phytophthora infestans) foliar epidemics with fungicides. Crop Prot. 21:575-582.

25. Stein, J. M., Kirk, W. W., and Niemira, B. A. 1998. The Role of Select Fungicides Within a Potato Late Blight Program: Antisporulation and Tuber Blight Aspects. Annual Meeting of the Potato Association of America, Somerset, NJ

26. Sujkowski, L. S., Fry, B. A., Power, R. J., Goodwin, S. B., Peever, T. L., Hamlen, R. A. and Fry, W. E. 1995. Sensitivities of Mexican isolates of Phytophthora infestans to chlorothalonil, cymoxanil, and metalaxyl. Plant Dis. 79:1117-1120.

27. Young, D. H., Spiewak, S. L., and Slawecki, R. A. 2001. Laboratory studies to assess the risk of development of resistance to zoxamide. Pest Manage. Sci. 57:1081-1087. 